\title{
Verstek Divorce Case in the Perspective of Positive Law and Islamic Law
}

\author{
A. Taufik ${ }^{1}$
}

\begin{abstract}
The research problem is that, in examining the verstek of the divorce case, the judge asked the plaintiff to prove the argument of the lawsuit with written evidence and / or witnesses, even though the verstek provisions did not regulate that. What is the legal basis of evidence regarding the subject matter in verstek and why did the defendant choose not to attend the trial and how is the verzet examination of divorce cases in court. how to study literature. While the data analysis method used is descriptive normative, that is, the method used to describe the norms on which the judge accepts, examine and resolve cases that emphasize the aspect of the prevailing legislation. Based on the analysis, it can be seen that the reason the judge ordered proof is: In the case of the verstek case of divorce cases, the principle of Lex Specialis Derogat Lex Generali is applied, therefore divorce cases are an exception to the HIR provisions. Because proof can show more of a legal function in providing a sense of justice and protection to society. Proof is useful to know the truth of the plaintiff's claim whether the lawsuit has legal grounds and does not violate rights. The formulation of Article 125 paragraph (1) HIR does not contain the words 'must', but instead the word 'accepted' is used.

Apart from basing it on positive legal provisions, in the version of divorce cases, the panel of judges also based on the doctrine in the Fiqh Books in the form of syar'iyah evidence. In a divorce case what is sought is material truth, not mere formal truth. It can be seen from the verdicts in divorce cases both recognized and in the verstek verdict, still undergoing a proving process. Both positive law and Islamic law see the need for proof in a verdict from a divorce case.
\end{abstract}

Keywords : Verstek; Divorce Case; Positive Law; Islamic law.

\section{Introduction}

The facts show, that not only before the marriage law came into effect the divorce rate was very high, but now this is the case as can be seen by litigants at the Religious Courts. Most of them come to file divorce cases, not other cases that are also under the authority of the Religious Courts. There is also a fact that in this divorce case the opposing party (defendant) chose not to attend the hearing in the hope that the case would quickly end. Divorce, in fact, was both wanted by both parties before the case was submitted to the Court. In the end the case was decided without the presence of the defendant or verstek.

Apart from being reluctant, the defendant's absence was also because he was in an "unseen" state. In this case, there are 2 (two) possibilities that will occur, namely: maybe the defendant is still alive (exists), or it could be that the defendant has died (does not exist). Both in the statutory provisions are categorized as "the

\footnotetext{
${ }^{1}$ Religious Court Judge
} 
unknown place of residence in Indonesia" which means the summoning is done according to the provisions of Article 27 of Government Regulation Number 9 Year 1975 (hereinafter abbreviated to PP No. 9 Th. 1975) jo. Article 139 Compilation of Islamic Law (hereinafter abbreviated as $\mathrm{KHI}$ ). If the defendant is not present at the first trial and the defendant can prove the arguments for his claim, then on that very day the case is decided by granting the plaintiff's claim. However, if the plaintiff is not ready with evidence and / or witnesses, practice at the Batang Religious Court, the panel of judges gave the plaintiff the opportunity to prove the arguments of the lawsuit at the next trial, without calling the defendant again. Two calls by radio were sufficient to give the defendant an opportunity to find out about the lawsuit which would allow him to give an answer at trial. Unlike the defendants who were summoned at a clear address, the panel of judges needed to postpone the trial and order the Substitute Bailiff to summon the defendants once again (vide Article 126 HIR). Two calls by radio were sufficient to give the defendant an opportunity to find out about the lawsuit which would allow him to give an answer at trial. Unlike the defendants who were summoned at a clear address, the panel of judges needed to postpone the trial and order the Substitute Bailiff to summon the defendants once again (vide Article 126 HIR). Two calls by radio were sufficient to give the defendant an opportunity to find out about the lawsuit which would allow him to give an answer at trial. Unlike the defendants who were summoned at a clear address, the panel of judges needed to postpone the trial and order the Substitute Bailiff to summon the defendants once again (vide Article 126 HIR).

There are several opinions that have emerged among legal experts regarding the nature of divorce cases. Their opinions or thoughts are as follows:

First, Retnowulan Sutantio and Iskandar Oeripkartawinata in their book stated: In divorce cases, verstek decisions are sometimes passed. It can happen that such a verstek decision will be notified to the defeated party, the defendant who did not come, through the village head, sub-district head or through the posting of announcements in front of (now: Regency Government Office / Mayor; author) concerned. It is understandable that the losing party is generally not aware of the verdict, so the possibility of bringing up a challenge against the verdict is very small. Another case concerning decisions that are comdemnatoir in nature, in other words a verdict that contains a sentence, the possibility that those who follow do not know of a verdict that is detrimental to him is very small. Also the legislators provided him with such good protection that he would still have the opportunity to fight back (see Article 129 HIR). Therefore, the district court should be very careful in passing verstek decisions in divorce lawsuit, and judges should act wisely and wisely so as not to rush to impose verstek in a divorce suit, considering that the divorce decision is constitutive "). ${ }^{2}$

Second, opinion of H. Basiran Yusuf, former high judge of the Semarang Religious High Court, who stated: Based on Fiqih al-Qadla, cases decided by verstek must be verified, for example examining witnesses. Even if the defendant is "unseen" (where his residence is not known), in order to decide a case, apart from the testimony of witnesses, it must be confirmed by a strengthening oath or called

${ }^{2}$ Retnowulan and Iskandar Oeripkartawinata, 1989, , Hukum Acara Perdata dalam Teori dan Praktik, Mandarmaju, Bandung, p. 29 
yamin al-istidhar. ${ }^{3}$ Likewise Mukti Arto's opinion, which states that in divorce cases, judges must first prove the truth of the arguments of the claim (reasons) with sufficient evidence before passing the verstek.

Third, is the opinion of M. Fauzan and Edy Nurfuady, arguing: The application of the verstek institution by using 'ordinary procedures', such as a judge ordering to call the defendant more than twice, the judge requiring the plaintiff to submit evidence, presenting witnesses concerning the subject matter of the case is a misapplication of law. ${ }^{4}$ In his opinion that the application of vestek institutions should use a 'special occasion'. ${ }^{5}$

Fourth, contained in the Administrative and Technical Guidelines for the Religious Courts Book II, revised edition, the Supreme Court of the Republic of Indonesia (MARI), states: The sequence in the verzet (resistance) examination begins with reading the verstek verdict and the proof is borne by the defendant (originally the plaintiff) first. The challenger is burdened with the obligatory evidence to prove his rebuttal argument in his position as a defendant against the argument of the lawsuit and an exception can be made. The Defendant has the right to submit a replica and the challenger has the right to submit a duplicate, which is followed by opening the evidence and conclusions. ${ }^{6}$

Understanding this direction of the Supreme Court of the Republic of Indonesia, the author gets the impression that the verstek examination program does not prove the subject matter, of course, including the divorce case.

Fifth, There are two opposing opinions among legal practitioners in the Religious Courts, some of which argue that the divorce case applies a procedure of proof regarding the subject matter of the case, while others argue that it is not necessary. However, the strong current has chosen to use the evidentiary program as can be seen from the decisions made by the Batang Religious Court.

The verstek decision referred to here is the verstek with a positive verdict, namely a decision that grants the plaintiff's claim.

It is common knowledge that divorce cases are the largest number of cases in the Religious Courts. This is the case at the Batang Religious Court. What is also interesting is that most of the divorce cases were terminated by verstek, which in 2009 reached $90 \%$.

Starting from the description above, the problem is as follows: To what extent is the divorce rate in the Batang Religious Court? What is the legal basis for the divorce case at the Batang Religious Court? Why is the divorce rate by verstek at the Batang Religious Court so striking? How is the verstek of divorce cases according to positive law and according to Islamic law?

\section{Research methods}

\footnotetext{
${ }^{3}$ Nur Khoirin YD, et al. (Ed), Membedah Pengadilan Agama, Syari'ah Faculty IAIN Wali Songo with PPHIM (PTA Central Java), Gunung Jato Offset, Semarang, p. 260

${ }^{4}$ M. Fauzan and Nurfuady, 1997, " Lembaga Verstek dan Penerapanya", Mimbar Hukum, Nomor 35, Th VIII November-December, p. 86.

${ }^{5}$ Mukti Arto HA, 1996, raktik Perkara Perdata Pada Pengadilan Agama, Pustaka Pelajar, Yogyakarta, page 251

${ }^{6}$ Supreme Court-RI, 2009, Pedoman Teknis Administrasi dan Teknis Peradilan Agama, Book II, Jakarta
} 
This research is a descriptive analytic study. This research is a normative juridical legal research. Data source in the form of primary data, obtained through interviews with research subjects / respondents regarding matters related to the object of research. Secondary data, in the form of: primary legal materials, secondary legal materials, and tertiary legal materials, namely legal materials that can provide instructions and explanations for primary and secondary legal materials, namely in the form of legal dictionaries, Indonesian dictionaries and legal encyclopedias. The data that had been collected were qualitatively descriptive and analyzed non-statistically. The use of inductive analysis is used to draw conclusions based on existing data after comparing one another. Also an empirical method, which is based on the author's experience.

\section{Results and Discussion}

\subsection{Divorce Case at the Batang Religious Court.}

Divorce cases which consist of divorce talak and divorce suit turned out to be the most (dominant) cases in the Batang Religious Court. The divorce filed by the wife (divorce sue) turns out to be more than the divorce filed by the husband (divorce talak). Both the divorce and divorce that were submitted to the Batang Religious Court were mostly granted by the Panel of Judges. The divorce filed by the wife, which is the largest number of cases in the Batang Religious Court, is due to immoral violations.

Divorce can occur for reasons or reasons as stated in Article 39 of Law no. 1 year 1974 and his explanation Jo. Article 19 PP No. 9 th. 1975 and Article 116 KHI.

If proxied, divorce cases with non-divorce will show a figure of $97.3 \%$ compared to $2.7 \%$ (polygamy permits, marriage dispensation, adoption, guardian adlal, marriage certificate, inheritance, etc.).

\subsection{Verstek Legal Basis for Divorce Case}

Studying case files in general, and especially verstek cases at the Batang Religious Court, there are many things that need to be stated here, namely as follows: First, that the verstek verdict was passed in the second or third trial, but mostly in the second trial; Second, there is a legal consideration that the defendant has been summoned formally and properly, but the defendant or his attorney is not present at the trial; Third, that the panel of judges always holds a proving program regarding the subject matter of a case before deciding a case, both documentary evidence and witnesses; Fourth, whereas there are two kinds of verstek, namely: 1) the defendant residing at a clear address and summoned to that address, but he did not want to be present at the trial; 2) the Defendant had an unclear address in the territory of Indonesia who was summoned through the mass media who was also not present at the trial; Fifth, whereas verdicts in divorce cases, the panel of judges in their legal considerations are always based on statutory regulations or positive law and also based on the principles of Islamic law.

The legal basis for the verstek decision is Article 125 paragraph (1) and 
Article 126 HIR. The application of this procedural law to the Religious Courts is based on Article 54 of Law no. 7 Th. 1989 which was most recently amended by Law no. 50 th. 2009 Concerning Religious Courts. In addition, it is also based on the principles of fiqhiyah or syar'iyyah hujjah-hujjah.

The arguments or evidence of syar'iyyah are contained in the Nash Association and Hujjah Syar'iyah Decisions / Rulings of the Religious Courts by A. Wasit Aulawi MA et al., Are as follows:

- "Whoever is summoned by the judge to attend the trial but does not appear before, then he has committed wrongdoing so that his right of reply will be null and void".7

- "And if the defendant is unable to attend because of hiding or is reluctant, then the judge may accept the witness' testimony and pass the law on it." 8

- "People who hide or do not heed orders (reluctantly), then the case may be decided without swearing at the opponent". ${ }^{9}$

- "Deciding a case against someone who is unseen is allowed, if there is evidence to support it". 10

- "Judges may accept evidence (testimony) and establish laws against unseen people outside their area." 11

In the Positive Law, it is clear that the evidentiary procedure in divorce cases is a necessity, whether there is recognition or there is no acknowledgment as in the verstek decision; even more so when there is an objection from the opposing party. Meanwhile, according to the opinion of jurisprudence experts, there are differences as stated in the arguments number 2 and number 3 above. Theorem number 2, from the words "the judge may accept the testimony of witnesses and make a verdict on it", means that in verstek it is not necessary for the witnesses to corroborate the argument of the lawsuit; on the other hand, the argument number 3 is from the words "without swearing to the opponent. ", It seems that there is no need for proof in the verstek decision. As for the arguments number 4 and number 5.

From what the authors have stated above, it can be concluded that between the Positive Law system on the one hand, and the Islamic Law system reflected in Sya'iyah's arguments on the other hand, actually complement each other. A decision will be more weighty and convincing to justice seekers who accept the verdict, let alone the Religious Court as a special court for people who are Muslim. Its inclusion is still needed after UUNo.7 Th.1989 and KHI because both of them will not be able to meet the legal needs of a society that is always developing, as well as providing an ideological and philosophical foundation in its application as well as the satisfaction of judges and justice seekers, especially among students.

\subsection{Divorce with Verstek at the Batang Religious Court.}

\footnotetext{
${ }^{7}$ A Wasit Aulawi, MA et al, 1978 Himpunan Nash dan Hujjah Syar'iyyah Putusan Pengadilan Agama, Development Project for the Religious Courts, Ministry of Religion, Jakarta, p. 125

8Ibid., P. 116

9Ibid., P. 117

10Ibid., P. 118

11Ibid h. 119
} 
Divorce at the Batang Religious Court which was decided by verstek showed a fantastic number, reaching $90 \%$ (the author's note as chairman of the assembly). The defendant's absence seems to have been intentional with the perception that the case settlement process would be faster than the defendant was present at the trial. What is clear is that by not attending, peace efforts through mediation cannot be implemented or do not exist.

Many of the plaintiffs who registered and during the trial were escorted by the Head of People's Welfare (Modin) in their village or were escorted by the local Marriage Registration Officer (PPN) or people who were used to "guide" the litigants at the Batang Religious Court. Their association or interaction with officials of the Religious Court made them more or less aware of the ins and outs of the trial process, including the verstek process of proceedings. It was not impossible for these introducers to influence the defendant so that he did not have to be present at the trial so that the case was quickly concluded. Thus, it is not surprising that the number of divorce cases decided is very high.

Verstek decisions mostly occur in suicidal divorce cases, which are the most cases in the Batang Religious Court. The husbands who became defendants mostly ignored the summons and chose not to attend the trial. On the other hand, in the divorce divorce case, the defendant attended because there was an interest in demanding his rights. In the case of a divorce, the respondent usually just surrenders to the wishes of the applicant who has "prerogative" rights to divorce or the respondent submits it to the court, provided that her rights as an ex-wife can be fulfilled following a divorce permit decision from the Court. It is hoped that the applicant (husband) or the judge will accept the response submitted by the respondent before the court to make decisions ex officio in the favor of the respondent.

\subsection{Verstek Divorce Case According to Positive Law and According to Islamic Law.}

Comparative review, which is a review with respect to and based on comparisons. Comparing the existing provisions in the articles of the prevailing laws and regulations with the legal principles in the realm of Islamic civilization. Including positive law is law. No.1 Th. 1974, PP. No. 9 th. 1975, UU.No. 7 Th. 1989, KHI, HIR etc. Especially for KHI, the author positions it as Positive Law, because it has been instructed by the Government through Presidential Instruction No. 1 of 1991 to make it the applied law of the Religious Court. Whereas Islamic Law, is in accordance with the Circular of the Bureau of Religious Courts of the Department of Religion Number B / I / 1735 dated February 18, 1958 to guide the 13 books of Fiqh in judging and resolving cases.

In addition to the similarities between the verses on divorce cases according to positive law and the divorce cases according to Islamic law, there are also differences.

Qualitatively, the similarities and differences are as follows: The similarity, both in Positive Law and in Islamic Law, the divorce case version requires evidence of the arguments of the lawsuit / petition.

The differences are as follows: 
- In Positive Law, the basic verstek of divorce cases is Article 125 paragraph (1) and 126 HIR, Article 27 paragraph (4) PP. No. 9 th. 1975 and Article 139 paragraph (4) KHI.

- In Islamic law, it is the syar'iyyah evidence which is the opinion of the scholars of jurisprudence.

- In Positive Law, the basis for proving a divorce case is Article 54 of Law no. 7 Th. 1989 which adopted the entry into force of Article 57, State Gazette No.7 of 1933, Article 22 PP No.9 Th. 1975 and Article 134 KHI.

- In Islamic law, the legal basis for proving verstek in divorce cases: First, doctrine, which is in the form of syar'iyyah evidence which is taken over as the opinion of the council, although the syar'iyyah evidence itself does not specifically regulate divorce cases. Second, is the hadith fi'ly Rasulullah Saw. who seek material truth in handling civil cases submitted to him. Third, the understanding that what is the object of a divorce case is the dissolution of a marriage bond known as mitsaqan ghalidza (a solid agreement), so that it is appropriate to distinguish it from the dissolution of the agreement in general, namely that evidence is needed to support the arguments of the lawsuit. Fourth, understanding that divorce is something lawful but is hated by Allah SWT and divorce can thrill 'Arsy, it is best avoided. However, in a state of necessity or emergency (emergency), divorce is permitted when there are proven reasons. Fifth, philosophically if it is in the Law. No. 1 year 1974 there is a principle of family participation when a person is married, so in a divorce the family who is questioned should be involved in the hearing as a witness.

To complete this description, it is necessary for the author to present the sound of the articles which are used as the basis for proving the divorce case and its verses.

- Article 57 LN No. 7 Th. 1933: The District Court, in a divorce case, is obliged to independently (self-stand) conduct an examination of the correctness of the reasons put forward to determine the divorce.

- Article 22 PP. No.9 Th. 1975: (1) A divorce suit for reasons stated in Article 19 letter $\mathrm{f}$, is filed before the court at the residence of the defendant; (2) The claim referred to in paragraph (1) can be accepted if it is clear enough to the court regarding the causes of the dispute and dispute and after hearing from the family and people close to the husband and wife.

- Article 27 paragraph (4) PP. No.9 Th. 1975: In the event that the summons as referred to in paragraph (2) have been made and the defendant or his attorney remains absent, the claim is accepted in the absence of the defendant, unless the lawsuit is without rights or groundless.

- Article 134 KHI: Divorce lawsuit for reasons as stated in Article 116 letter f, can be accepted if it is clear enough to the Religious Court regarding the causes of the dispute and quarrel and after hearing from the family and people close to the husband and wife.

- Article 139 paragraph (4) KHI: In the event that it has been carried out as referred to in paragraph 2 (two) and the defendant or his attorney is still absent, the lawsuit is accepted without the defendant's presence, unless the lawsuit is without rights or groundless. 
Thus, what is also a difference is that in the Positive Law the basic verstek of divorce cases is explicitly stated in the articles of the existing laws and regulations as the author mentioned above; whereas in Islamic Law the judge extracts from the treasures of procedural law recorded in the history of Islamic Justice from the opinion of jurisprudence or doctrine experts in the form of syar'iyyah evidence.

\section{Closing}

\subsection{Conclusion}

Based on the description above, it can be concluded: The legal basis for the Batang Religious Court dropping the verstek of divorce cases originating from the Positive Law are Articles 125 and 126 HIR which are justified from the provisions of Article 54 of Law No.7 Th.1989 amended by Law No. 3 Th. 2006 and modified again with UUNo. 50 th. 2009 concerning Religious Courts. While the legal basis that comes from Islamic law, is the evidence of syar'iyyah which is contained in the books of Fiqh. Examination of the verstek of a divorce case requires proof of the subject matter of the case, namely by examining evidence, including witnesses. Both in Positive Law and in Islamic Law there are provisions regarding the need for a proof program in terms of technology, as well as in divorce case verses. The Defendant chose not to attend the trial so that the trial process could quickly end. Qualitatively, there are similarities and differences between the verses on divorce cases according to positive law and the verses on divorce cases according to Islamic law. In positive law, basically it is explicitly stated in the articles of statutory regulations, whereas in Islamic law it is based on doctrine and opinion of judges.

\subsection{Suggestions}

- In order to carry out their duties, try to meet the defendant at their place of residence. If forced to not be able to meet the defendant, then to the Village Head or other equivalent officials, a summons is entrusted so that it is submitted to the person concerned. In order for summons to be truly delivered and not taken for granted, it is necessary to think about incentives for them. It turned out that there was a village head who objected to accepting summons on the grounds that there was no cost.

- In the context of actualizing the normalization of Islamic Law, the points of Islamic Procedural Law need to be formalized as National Law or Positive Law. In this era of reform, the momentum for creating laws that are appropriate to the current conditions of Indonesian society is by law-making institutions.

\section{Bibliography}

[1] A Wasit Aulawi, MA et al, 1978 Himpunan Nash dan Hujjah Syar'iyyah Putusan Pengadilan Agama, Development Project for the Religious Courts, Ministry of Religion, Jakarta.

[2] M. Fauzan and Nurfuady, 1997, "Lembaga Verstek dan Penerapanya", Mimbar Hukum, Nomor 35, Th VIII November-December. 
[3] Mukti Arto HA, 1996, raktik Perkara Perdata Pada Pengadilan Agama, Pustaka Pelajar, Yogyakarta.

[4] Nur Khoirin YD, et al. (Ed), Membedah Pengadilan Agama, Syari'ah Faculty IAIN Wali Songo with PPHIM (PTA Central Java), Gunung Jato Offset, Semarang.

[5] Retnowulan and Iskandar Oeripkartawinata, 1989,, Hukum Acara Perdata dalam Teori dan Praktik, Mandarmaju, Bandung

[6] Supreme Court-RI, 2009, Pedoman Teknis Administrasi dan Teknis Peradilan Agama, Book II, Jakarta 